A rich store of Thornton's letters and diaries is in the possession of the Bodleian, held by the Rhodes House Library at Oxford, and further papers are to be found in the Archives in Salisbury, Southern Rhodesia. These sources are supplemented by Thornton's diaries covering both his East African and Zambezi work in the possession of the Rhodes-Livingstone Museum at Livingstone, Northern Rhodesia.

The Kilimanjaro diary was prepared for publication by Thornton's brother George, even to the extent of commissioning Thomas Baines to paint the frontispiece, but the executors of von der Decken invoked the terms of the agreement between the two explorers to prohibit its publication. H. A. Fosbrooke has now undertaken the editing of this diary, which it is hoped to issue next year, sponsored by the Rhodes-Livingstone Museum and published by Chatto \& Windus, in the new 'Robins Series' of works on Central and Southern Africa. The Zambezi diaries are being edited by J. H. Chaplin, Inspector of Monuments, Northern Rhodesia, and will be published in the same series.

[Communicated by H. A. Fosbrooke, Director, Rhodes-Livingstone Institute]

\title{
The Historical Society of Nigeria, Fifth Annual Congress
}

TuE Fifth Annual Congress of the Historical Society of Nigeria was held at Enugu on 20, 21 , and 22 December 1959. The theme of the Congress was 'Nigerian History'. It is hoped to publish a more detailed account of the Congress in a forthcoming issue of Africa.

\section{Ford Foundation Grant to the East African Institute of Social Research, Makerere College}

THE Ford Foundation has made a grant for assistance to the East African Institute of Social Research, in the establishment of an Applied Research Unit. The Institute's staff and its associated research workers have been engaged for over ten years in numerous studies designed to increase knowledge of social and economic conditions in East Africa, and the central task of the Institute will continue to be basic research of this type which, in addition to increasing the store of fundamental knowledge available, often provides information of immediate practical use. An additional need exists, however, for the solution of specific problems which arise for Central and Local Governments, industrial organizations, and other bodies concerned with developments in East Africa. The new Unit will be particularly concerned with this type of research, which has a definite practical objective.

The grant will make possible the appointment of a Research Secretary and three research workers for a period of at least three years, and it is hoped that the results of the work of the Applied Research Unit will be such that it will be enabled to continue its work, after the end of the Ford Foundation Grant, with assistance from the various governments and private bodies who may use the Unit.

\section{Training in Community Development}

The Ghana Government proposes to renew its offer of four fellowships and two scholarships for training in community development. The training will start early in March 1960: that provided under the fellowships lasting six months, and under the scholarships a year. It will be mainly practical, consisting of attachment to the Department of Social Welfare and Community Development in Ghana. Particulars of the I959 training programme, which will form the model for the I960 programme, are given below.

The 1960 awards will be made by the Government of Ghana to persons nominated by the governments of their respective countries. Candidates for the fellowships should already possess some experience as government officials, of working with rural people, and some knowledge of, and interest in, the principles of community development. They should 